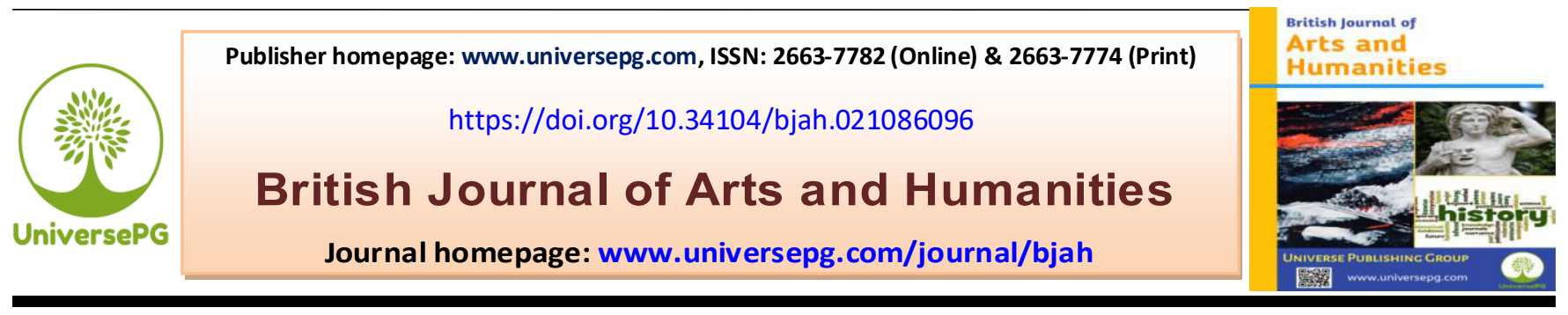

\title{
Learning Styles \& Academic Performance of Teacher Education Students
}

\section{Bernadette A. Cada*}

Eastern Samar State University, Borongan City, Eastern Samar, Philippines, 6800.

*Correspondence: dettec1023@gmail.com (Dr. Bernadette A. Cada, Professor, College of Education (English Language), Eastern Samar State University, Borongan City, Eastern Samar, Philippines).

\begin{abstract}
Individual differences can be attributed to learning styles across students. It is the goal of this research to determine the students' preferred learning styles and how well they performed academically. This study is a descriptive-correlation method of research on learning style and academic performance of teacher education students. The results revealed that: The first year teacher education students have varied learning styles with social learning style as the most dominant. This implies that the first year teacher education students prefer to learn in groups or with other people; The rating of the first year teacher education students ranges from 1.6-2.0 which is equivalent to "very good" in the adjectival rating based on the grading system of the university; and The correlation analysis using the Pearson's Product Moment Correlation of Coefficient result to a p-value which is greater than the level of significance (0.05) for all learning styles which means that there is no correlation between students' chosen learning techniques and their academic success.
\end{abstract}

Keywords: Academic performance, Learning styles and Teacher education students.

\section{INTRODUCTION}

Learning styles of students has been widely deliberated in both conceptual and research literature. As pointed out by Kolb, (1999), an important area of personal competence for college students in learning style, that is, how individuals approach a thing that is new to him. This may be a means of identifying incoming college students who are at risk for academic difficulty. Lawrence as cited by De la Cruz, (2006) stated that learning styles involve four cognitive approaches in a learner, namely: a) preferred of habitual patterns of mental functioning; b) patterns of attitudes and interest that influence the learner's choice as to what aspect to pay most attention to in a given learning situation; c) a tendency to use situations that are comparable with one's own learning patterns; and d) a tendency to use certain learning strategies and avoid others. Oxford, (2001) stated that a learning style often determines the choice of what she referred to as L2 Learning Strategies. She cited as an example the case of an analyticstyle students who prefer such strategies categorized as: contrastive analysis, rule learning, dissecting words and phrases. On the other hand, global students used strategies to find meaning such as guessing, scanning and predicting as well as to converse without knowing all the words through such strategies as paraphrasing and gesturing. Further Oxford, (2001) pointed out those students who were more tolerant of ambiguity use significantly different learning strategies in some instances than do students who are less tolerant of ambiguity. Whereas Felder, (1993) formulated the following learning styles based on the synthesis of other studies: 1) Sensing and intuitive perceptions wherein learners with sensing perception prefer information that comes through their senses while intuitive learners favor information that arises internally through 
memory, reflection and imagination; 2) Visual and verbal input - here visual learners get more information from visual images such as diagrams, graphs, pictures, schematic presentations, and demonstration than from verbal materials like spoken words and mathematical formula; 3) Inductive and deductive organization where inductive learners prefer to learn a teaching material by seeing specific cases first through such processes as observations, experimental results and numerical examples and working up to governing principles and theories by inference. Whereas, deductive learners prefer to begin with general principles upon which to deduce consequences and application; 4) Active and reflective processing - active learners learn and do something active, such as testing things out and discarding others. Reflective learners, on the other hand, connect ideas reflectively, looking at things in before putting them into practice.; 5) Sequential and global learners- global learners attain understanding in enormous "holistic leaps," as opposed to sequential learners who learn in small connected chunks. Sequential learners can solve problems with a partial understanding of the content, and their answers are often ordered and simple to follow, but they may not have a complete understanding of the situation. Global learners, on the other hand, operate in a more all-ornothing manner and may look and do poorly on homework and tests until they get the big picture.

However, after they have fully grasped the topic, principle, or procedure, they may often establish new connections to other disciplines that sequential learners are unable to do. Differences in learning styles among students can be attributable to the variations that exist among individuals in terms of mental actions which are directly responsible for learning outcomes. Broad foot as cited by Husen and Postlethwaite, (1994) indicated learning activities can involve four learning type categories, each with its own constituent processes, namely: associative learning, procedural learning, inductive reasoning and metacognition. The first category involves the rate and quality of forming associations between new and old knowledge. Procedural learning serves to establish relations between rules. Inductive reasoning involves the discovery of rules and principles. The last category of metacognition refers to one's personal knowledge of his/her learning abilities and limitations, including skills that enable the acquisition and application of knowledge and skills. The process underlying metacognition include: 1) defining a problem or goal in one's own words; 2) developing a plan to attain the goal; 3) allocating resources for en-acting the plan; 4) monitoring progress; 5) summarizing results (new knowledge and skills) into the existing knowledge structure.

Ornstein and Sinatra, (2005) posited the view that learning differences are not solely tied to the ability factors; rather we all have propensities that influence our thinking and guide our intellect. To illustrate, they cited the case of some learners who learn best alone, while others prefer to learn in small groups and share information. Accordingly, some students exhibit ontask persistence, whereas, others feel bored while taking notes or studying at home. Further, they state that some learn through hands-on activities and manipulative materials, while others are better able to digest abstract and verbal information. Dunn, (2005) developed a model for Learning Styles Inventory which is based on the following theoretical underpinnings: a) That everyone has strengths, but, different people have different strengths; b) That instructional materials, resources, and approaches should cater to diversified styles; c) That individual preferences exist and can be measured reliably; d) That most teachers learn to use learning styles as the cornerstone of instruction; and e) That students can learn to capitalize on their styles of learning. Many attempts have been made to improve students' academic performance. Many devoted teachers and parents have always been anxious that their students achieve as much success as necessary. Many teachers believe that students must have an optimistic response in order to achieve intellectually (Abidin, et al., 2011). Likewise, Dunn et al. (1989) assert that through voluminous studies, it has been indicated that both low and average achievers earn higher scores on standardized achievement and attitude tests when they are taught within the realm of their learning styles. Claim that extensive research has shown that when students are taught in the context of their learning styles, both poor and average performers do better on standardized achievement and attitude assessments. The implementation of the College of Education's increased retention policy demands the identification 
of freshman students' preferred learning modes, so learning activities should match. It is in this light that this study will be conducted so students' learning styles are identified to determine strengths for academic achievement.

\section{Objectives of the Study}

This study aimed to figure out which learning techniques is preferred and academic performance of teacher education students. It was guided by the following specific objectives:

1) To determine the preferred learning styles of teacher education students in ESSU main campus in terms of:
1.1 visual learning styles;
1.2 aural learning styles;
1.3 verbal learning styles;
1.4 physical learning styles;
1.5 logical learning styles;
1.6 social learning style; and
1.7 solitary learning styles

2) To determine the level of academic performance of teacher education students; and

3) To find out if there is a significant relationship between students' preferred learning styles and level of academic performance.

\section{Significance of the Study}

The importance of the study can be viewed more meaningfully to the following:

a) Teachers- Results of the study can be useful to teachers in planning strategies and enriching activities to cater to students' learning styles.

b) Curriculum Planners- The findings of this study will give insights and inputs in the improvement of the curriculum that would cater to the learning styles of the students in pursuing their careers.

c) Future Researchers- The findings of this study can be used as a guide and basis of comparison for related studies and conduct a study using other variables that affect the level of English comprehension.

\section{Scope and Delimitation of the Study}

The goal of this study was to find out how teacher education students of Eastern Samar State University main campusprefer to learn. This study is limited to the first year college students who are officially enrolled in the teacher education programs for the summer term of 2017 of ESSU main campus. A survey questionnaire UniversePG I www.universepg.com was used to gather data on the learning styles of respondents. Tally sheets were used to record the general weighted average of the students during the first semester of SY 2016-2017.

\section{MATERIALS AND METHODS:}

Research Design- The descriptive co relational method of research was used in this study using a questionnaire on learning style inventory. This inventory known as the Memletics Learning Styles Inventory (MLSI) was obtained online. A tally sheet of the general average of second year teacher education students of ESSU main campus was used.

Research Locale- The study was conducted at the College of Education of ESSU main campus, Borongan City, Eastern Samar.

Respondents of the Study- The respondents in the study are the first year teacher education students of ESSU main campus who are officially enrolled during the summer term of 2017. As they prepare to enrol in higher education courses, it is essential to know their learning styles so that activities may be tailored to their preferences.

Research Instrument- The instrument on MLSI was used. This is a seventy (70) item test designed to measure the learning styles of students and it has 10 items for each indicator. The teacher education students were tasked to indicate the extent of their preference in accomplishing a task using the following categories: (0) Nothing like Me; (1) Somewhat Like Me; and (2) Very Much like Me. The questionnaire has seven scales of learning styles such as visual, aural, verbal, physical, logical, social, and solitary.

Data Gathering Procedure- The researcher personally administered the questionnaire on Memletics Learning Styles Inventory. The collection of data commenced during summer 2017 since they have summer classes. After the respondents have answered the questionnaire, the researcher immediately retrieved the instrument from them. The grades of the respondents for the first semester, SY 2016-2017 were taken from the Registrar's Office, and recorded in the tally sheets.

Measurement of Variables- The profile of the students was measured in terms of the following variables and scales. As to the learning styles, the following are the categories: 


$\begin{array}{ll}\text { Score Range } & \text { Interpretation } \\ 17-20 & \text { always practiced } \\ 13-16 & \text { very often practiced } \\ 9-12 & \text { often practiced } \\ 5-8 & \text { seldom practiced } \\ 1-4 & \text { never practiced }\end{array}$

For the General Average, the following are the categories patterned after the equivalent rating and adjectival rating as reflected in the report of grades of the university (Revathy and Peruvalluthi, 2020).

$\begin{array}{ll}\text { Category/Scale } & \text { Description } \\ 1.00 & \text { Outstanding } \\ 1.1-1.5 & \text { Excellent }\end{array}$
$1.6-2.0$
Very Good
$2.1-2.5$
Good
$2.6-3.0$
Fair

Data Analysis- The data elicited from the respondents were tallied, computed and treated using the appropriate statistical measure. A computerized statistical analysis was employed to facilitate statistical computation.

\section{RESULTS AND DISCUSSION:}

Learning styles of teacher education students. The succeeding tables present the preferred learning styles of teacher education students of ESSU main campus.

Table 1: Learning Style of Teacher Education Students.

\begin{tabular}{|c|c|c|}
\hline Learning Styles & Mean & Interpretation \\
\hline Visual learning style & 11.19 & Often Practiced \\
\hline Verbal learning style & 13.19 & Very Often Practiced \\
\hline Aural learning style & 12.29 & Often Practiced \\
\hline Physical learning style & 12.09 & Often Practiced \\
\hline Logical learning style & 12.22 & Often Practiced \\
\hline Social learning style & 13.51 & Very Often Practiced \\
\hline Solitary learning style & 12.29 & Often Practiced \\
\hline TOTAL & 12.39 & Often Practiced \\
\hline
\end{tabular}

The learning style of teacher education student's revealed that social learning style obtained the highest mean which is 13.51 , followed by verbal learning style which is 13.19 , and these mean "very often practiced". Other learning styles are "often practiced" such as aural learning style with a mean of 12.29 , and solitary learning style which obtained similar mean of 12.29 , logical learning style got 12.22, while physical learning style got 12.09. The visual learning style obtained the lowest mean of 11.19 which also means "often practiced". The overall mean of the respondents' learning styles is 12.39 which means "often practiced".

As gleaned on Table 2 visual learning style of teacher education students, the item on "You have a good sense of color" obtained the highest mean of 1.51 which is interpreted as "very much like me", followed by the item "You like books with many diagrams, illustrations and pictures" with a mean of 1.45 which means "somewhat like me". The items on "You can easily visualize objects, buildings, scenarios, etc., from descriptions or plans", and "You like using a camera or video camera to capture the world around you" have the same mean of 1.38 interpreted as "somewhat like me". Other items with similar mean of 1.12 interpreted as "somewhat like me" are items "You find your way around well, use maps with ease. You rarely get lost. You have a good sense of direction. You usually know which way North is", and "You like tinkering. You like pulling things apart and they usually go back together. You can easily follow instruction represented in diagrams".

The item "You like visual arts, painting and sculpture. You like jigsaw and mazes" got 1.09 which means "somewhat like me", and this is followed by the item "You use diagrams and scribbles to communicate ideas and information. You use white boards", obtained 1.03 which means "somewhat like me". The items "You draw well. You find yourself drawing, doodling on a notepad when thinking" and "In school, you prefer art, technical drawing or geo-metry obtained the lowest mean scores of 0.54 and 0.51 which mean "nothing like me". The overall mean of the respondents' visual learning style is 1.11 inter-preted as "somewhat like me". 
Table 2: Visual Learning Style of Teacher Education Students.

\begin{tabular}{|c|c|c|}
\hline Visual Learning Style & Mean & Interpretation \\
\hline $\begin{array}{c}\text { You can easily visualize (see in your mind) objects, Buildings, scenarios, etc., from } \\
\text { descriptions or plans. }\end{array}$ & 1.38 & Somewhat Like Me \\
\hline $\begin{array}{c}\text { You find your way around well use maps with ease. You rarely get lost. You have a } \\
\text { good sense of direction. You usually know which way North is. }\end{array}$ & 1.12 & Somewhat Like Me \\
\hline In school you prefer art, technical drawing or geometry. & 0.51 & Nothing Like Me \\
\hline You like using a camera or video camera to capture the world around you. & 1.38 & Somewhat Like Me \\
\hline You like books with many diagrams, illustrations and pictures. & 1.45 & Somewhat Like Me \\
\hline You have a good sense of color. & 1.51 & Very Much Like Me \\
\hline You draw well. You find yourself drawing, doodling on a notepad when thinking. & 0.54 & Nothing Like Me \\
\hline $\begin{array}{c}\text { You use diagrams and scribbles to communicate ideas and information. You use } \\
\text { whiteboards (and color pens) }\end{array}$ & 1.03 & Somewhat Like Me \\
\hline $\begin{array}{c}\text { You like tinkering. You like pulling things apart, and they usually go back together. } \\
\text { You can easily follow instructions represented in diagrams. }\end{array}$ & 1.12 & Somewhat Like Me \\
\hline You like visual arts, painting and sculpture. You like jigsaw and mazes. & 1.09 & Somewhat Like Me \\
\hline TOTAL & 1.11 & Somewhat Like Me \\
\hline
\end{tabular}

On verbal learning style of teacher education students shown in Table 3 below, the item "You love telling stories" got the highest mean of 1.45 which means "somewhat like me", followed by items "In regular conversation, you often bring up other topics or events you have heard about or read" and "You like crossword, scrabble and other word games" got a mean of 1.41 which means "somewhat like me". Three items "You read everything, books, newspapers, magazines, menus, signs, etc.", "You easily express yourself, whether it's out loud or in writing. You can clearly explain ideas and information to others" and "You easily absorb information through reading, audio-cassettes or lectures. The actual words and phrases come back to you" obtained a mean of 1.38 which mean "somewhat like me". The item "You know lots of words and like using the right word at the right time" got a mean of 1.25 which means "somewhat like me", while the item "English, languages and literature are your favorite subjects at school" obtained a mean of 1.22 which means "somewhat like me". The item "You solve problems by "thinking aloud". You talk through issues, questions and other possible solutions" got a mean of 1.19 which means "somewhat like me" and the item "You like playing with the meaning of words, saying tongue twisters, making rhyme" obtained a mean of 1.09 which means "somewhat like me". The overall mean of the respondents' verbal learning style is 1.31 interpreted as "somewhat like me".

Table 3: Verbal Learning Style of Teacher Education Students.

\begin{tabular}{|c|c|c|}
\hline Verbal Learning Style & Mean & Interpretation \\
\hline You read everything, books, newspapers, magazines, menus, signs, etc. & 1.38 & Somewhat Like Me \\
\hline $\begin{array}{c}\text { In regular conversation, you often bring up other topics or events you have heard about } \\
\text { or read. }\end{array}$ & 1.41 & Somewhat Like Me \\
\hline English, languages and literature are your favorite subjects at school. & 1.22 & Somewhat Like Me \\
\hline You love telling stories. & 1.45 & Somewhat Like Me \\
\hline You know lots of words and like using the right word at the right time. & 1.25 & Somewhat Like Me \\
\hline You easily express yourself, whether it's out loud or in writing. You can clearly & 1.38 & Somewhat Like Me \\
\hline You like playing with the meaning of words, saying tongue twisters, making rhyme. & 1.09 & Somewhat Like Me \\
\hline You like crossword, scrabble and other word games. & 1.41 & Somewhat Like Me \\
\hline You solve problems by “thinking aloud”. You talk through issues, questions and other & 1.19 & Somewhat Like Me \\
possible solutions. & 1.38 & Somewhat Like Me \\
\hline You easily absorb information through reading, audiocassettes or lectures. The actual & 1.31 & Somewhat Like Me \\
\hline words and phrases come back to you. & &
\end{tabular}


Table 4: Aural Learning Style of Teacher Education Students.

\begin{tabular}{|c|c|c|}
\hline Aural Learning Style & Mean & Interpretation \\
\hline Jingles, themes or part of songs pop into your head at random. & 1.19 & Somewhat Like Me \\
\hline $\begin{array}{l}\text { You like listening to music - in the car, studying, at work (if possible!), or anywhere. You } \\
\text { love live music. }\end{array}$ & 1.80 & $\begin{array}{l}\text { Very Much Like } \\
\text { Me }\end{array}$ \\
\hline Music is your favorite subject at school, or you like playing in a band. & 0.80 & Nothing Like Me \\
\hline $\begin{array}{c}\text { You use rhythm or rhyme to remember items, for example, phone numbers, PIN numbers } \\
\text { and other items. }\end{array}$ & 1.38 & Somewhat Like Me \\
\hline $\begin{array}{l}\text { You pay attention to the sounds around you. You can tell the difference between } \\
\text { instruments, or cars, or aircraft based on their sound. }\end{array}$ & 1.51 & $\begin{array}{l}\text { Very Much Like } \\
\text { Me }\end{array}$ \\
\hline You can play a musical instrument or you can sing on (or close to) key. & 0.83 & Nothing Like Me \\
\hline $\begin{array}{l}\text { You occasionally realize you are tapping in time to music, or you naturally start to hum or } \\
\text { whistle a tune. Even after only hearing a tune a few times you can remember it. }\end{array}$ & 1.48 & Somewhat Like Me \\
\hline $\begin{array}{l}\text { You don't like silence. You would prefer to have some background music or other noise } \\
\text { to silence. }\end{array}$ & 1.22 & Somewhat Like Me \\
\hline You hear small things that others don’t. & 0.87 & Nothing Like Me \\
\hline $\begin{array}{l}\text { Music evokes strong emotions and images as you listen to it. Music is prominent in your } \\
\text { recall of memories. }\end{array}$ & 1.35 & Somewhat Like Me \\
\hline TOTAL & 1.37 & Somewhat Like Me \\
\hline
\end{tabular}

Table 5: Physical Learning Style of Teacher Education Students.

\begin{tabular}{|c|c|c|}
\hline Physical Learning Style & Mean & Interpretation \\
\hline $\begin{array}{c}\text { You love sport and exercise. } \\
\text { others. }\end{array}$ & 1.06 & Somewhat Like me \\
\hline $\begin{array}{c}\text { You use many hand gestures or other physical body language when communicating with } \\
\text { You like making models, or working out jigsaws. }\end{array}$ & 1.51 & Very Much Like Me \\
\hline $\begin{array}{c}\text { In school, you like sports, wood or metalworking, craft, sculpture, pottery and other similar } \\
\text { subjects. }\end{array}$ & 0.80 & Nothing Like Me \\
\hline You notice and like the feel of clothes, furniture and other objects. & Nothing Like Me \\
\hline You like to think out ideas, problems, or issues while doing something physical. & 1.41 & Somewhat Like Me \\
\hline $\begin{array}{c}\text { You love theme park rides that involve much physical action, or you dislike them because } \\
\text { you are sensitive to the physical forces on your body. }\end{array}$ & 1.03 & Somewhat Like Me \\
\hline You would prefer to touch or handle something to understand how it works. & 1.00 & Somewhat Like Me \\
\hline You like gardening or working with your hands in the shed. & 1.64 & \\
\hline TOTAL & 1.06 & Very Much Like Me \\
\hline & 1.14 & Somewhat Like Me \\
\hline
\end{tabular}

As reflected on Table 4 aural learning style, item "You like listening to music - in the car, studying, at work (if possible!), or anywhere. You love live music" got a mean of 1.80 which means "very much like me", this is followed by item "You pay attention to the sounds around you. You can tell the difference between instruments, or cars, or aircraft based on their sound" with a mean of 1.51 which means "very much like me". The item "You occasionally realize you are tapping in time to music, or you naturally start to hum or whistle a tune. Even after only hearing a tune a few times you can remember it" got 1.48 interpreted as "somewhat like me", "You use rhythm or rhyme to remember items, for example, phone numbers, PIN numbers and UniversePG I www.universepg.com other items" got 1.38 which means "somewhat like me", "Music evokes strong emotions and images as you listen to it. Music is prominent in your recall of memories" got 1.35 which means "somewhat like me", "You don't like silence. You would prefer to have some background music or other noise to silence" got 1.22 which means "somewhat like me", "Jingles, the-mes or part of songs pop into your head at random" got a mean of 1.19 which means "somewhat like me". There are three items which mean "nothing like me": "You hear small things that others don't" with a mean of 0.87; "You can play a musical instrument or you can sing on (or close to) key" got a mean of 0.83 ; and "Music is your favourite subject at school, or you like 
playing in a band" with a mean of 0.80 . The overall mean of respondents' aural learning style is 1.37 which means "somewhat like me"

Table 5 showed that physical learning style of teacher education students got the highest mean of 1.64 which means "very much like me" on the item "You would prefer to touch or handle something to understand how it works", and the item "You use many hand gestures or other physical body language when communicating with others" got a mean of 1.51 which also means "very much like me". The item "You notice and like the feel of clothes, furniture and other objects" got a mean of 1.41 which means "somewhat like me", "You enjoy dancing" got a mean of 1.25 which means "somewhat like me", "You love sport and exercise" and "You like gardening or working with your hands in the shed" got a similar mean of 1.06 which means "somewhat like me", "You love theme park rides that involve much physical action, or you dislike them because you are sensitive to the physical forces on your body" got a mean of 1.00 which mean "somewhat like me". There are two items "You like making models, or working out jigsaws" with a mean of .80 interpreted as "nothing like me" and "In school, you like sports, wood or metalworking, craft, sculpture, pottery and other similar subjects" got a mean of .070 which means "nothing like me". The overall mean of respondents' physical learning style is 1.14 interpreted as "somewhat like me". It can be gleaned on Table 6 on logical learning style of teacher education students, the items "You use a specific step-by-step process to work out problems" got a mean of 1.48 which means "somewhat like me". There are two items "You use specific examples and references to support your points of view" and "You like to understand how and why things work. You keep up to date with science and technology" got a mean of 1.45 which means "somewhat like me". Another two items "You write and use detailed lists, such as to-do lists and you number the items and set priorities" and "You enjoy finding links and associations, for example between number or objects.

You like to classify or group things to help you understand the relationship between them" have similar mean of 1.32 which mean "somewhat like me". "You can balance a checkbook or you know how much you have in your bank account/piggy bank. You like to set budgets and other numerical goals" got a mean of 1.20 which means "somewhat like me", "You like logic games and brainteasers. You like chess and other strategy games" got 1.19 which means "some-what like me", "You like identifying logic flaws or problems in other people's words and actions" got 1.09 which means "somewhat like me", "You prefer math and science subjects at school" got a mean of 1.00 which means "somewhat like me", and the lowest mean obtained is 0.74 which means "nothing like me" on the item "You easily work with numbers, and can do decent calculations in your head". The overall mean of the respondents' logical learning style is 1.22 interpreted as "somewhat like me".

Table 6: Logical Learning Style of Teacher Education Students.

\begin{tabular}{|c|c|c|}
\hline Logical Learning Style & Mean & Interpretation \\
\hline You write and use detailed lists, such as to-do lists and you number the items and set priorities. & 1.32 & Somewhat Like Me \\
\hline You prefer math and science subjects at school. & 1.00 & Somewhat Like Me \\
\hline $\begin{array}{l}\text { You enjoy finding links and associations, for example between number and objects. You } \\
\text { like to classify or group things to help you understand the relationship between them. }\end{array}$ & 1.32 & Somewhat Like Me \\
\hline $\begin{array}{l}\text { You can balance a checkbook or you know how much you have in your bank account/piggy } \\
\text { bank. You like to set budgets and other numerical goals. }\end{array}$ & 1.20 & Somewhat Like Me \\
\hline You like identifying logic flaws or problems in other people's words and actions. & 1.09 & Somewhat Like Me \\
\hline You use specific examples and references to support your points of view. & 1.45 & Somewhat Like Me \\
\hline You like logic games and brainteasers. You like chess and other strategy games. & 1.19 & Somewhat Like Me \\
\hline You easily work with numbers, and can do decent calculations in your head. & 0.74 & Nothing Like Me \\
\hline $\begin{array}{l}\text { You like to understand how and why things work. You keep up to date with science and } \\
\text { technology. }\end{array}$ & 1.45 & Somewhat Like Me \\
\hline You use a specific step-by-step process to work out problems. & 1.48 & Somewhat Like Me \\
\hline TOTAL & 1.22 & Somewhat Like Me \\
\hline
\end{tabular}


Table 7 below showed the social learning style of teacher education students. The highest mean obtained is 1.80 which means "very much like me" for items "You enjoy learning in classroom style surroundings with other people. You enjoy the contact and it helps your learning" and "You have some very close friends". This is followed by item "You like being a close friend, mentor or guide for others" with a mean of 1.74 which means "very much like me", "You like to listen. People like to talk to you because they feel you understand them" got 1.64 which means "very much like me", "You communicate well with others and you often help solve problems between two people" got a mean of 1.48 which means "somewhat like me", "You like playing games with others, such as card games and board games" got a mean of 1.29 which means "somewhat like me", "You like getting out of the house and being with others at parties and other social events" got a mean of 1.09 which means "somewhat like me", "You prefer to talk over problems, issues, or ideas with others, rather than working on them by yourself" got a mean of 1.06 which means "somewhat like me" (Weerakoon, 2020).

The two items "You don't mind taking the lead and showing others the way ahead" got a mean of 0.83 which means "nothing like me" and "You prefer team games and sports such as foot-ball/soccer, basketball, netball, volleyball, hockey, and baseball" got a mean of 0.74 which means "nothing like me". The overall mean of the respondents' social learning style is 1.34 interpreted as "somewhat like me".

Table 7: Social Learning Style of Teacher Education Students.

\begin{tabular}{|c|c|c|}
\hline \multicolumn{1}{|c|}{ Social Learning Style } & Mean & Interpretation \\
\hline $\begin{array}{c}\text { You enjoy learning in classroom style surroundings with other people. You enjoy the } \\
\text { contact and it helps your learning. }\end{array}$ & 1.80 & Very Much Like Me \\
\hline $\begin{array}{c}\text { You prefer team games and sports such as football/soccer, basketball, netball, volleyball, } \\
\text { hockey, and baseball. }\end{array}$ & 0.74 & Nothing Like Me \\
\hline You like being a close friend, mentor or guide for others. & 1.74 & Very Much Like Me \\
\hline You communicate well with others and you often help solve problems between two people. & 1.48 & Somewhat Like Me \\
\hline You like to listen. People like to talk to you because they feel you understand them. & 1.64 & Very Much Like Me \\
\hline You have some very close friends. & 1.80 & Very Much Like Me \\
\hline $\begin{array}{c}\text { You prefer to talk over problems, issues, or ideas with others, rather than working on them } \\
\text { by yourself. }\end{array}$ & 1.06 & Somewhat Like Me \\
\hline You like playing games with others, such as card games and board games. & 1.29 & Somewhat Like Me \\
\hline You like getting out of the house and being with others at parties and other social events. & 1.09 & Somewhat Like Me \\
\hline You don't mind taking the lead and showing others the way ahead. & 0.83 & Nothing Like Me \\
\hline TOTAL & 1.34 & Somewhat Like Me \\
\hline
\end{tabular}

Table 8: Solitary Learning Style of Teacher Education Students.

\begin{tabular}{|c|c|c|}
\hline Solitary Learning Style & Mean & Interpretation \\
\hline You have a personal or private interest or hobby that you like to do alone. & 1.58 & Very Much Like Me \\
\hline You are happy on your own. You like to do some activities alone and away from others. & 0.74 & Nothing Like Me \\
\hline You are goal oriented and know where you want to go in life, study or work. & 1.90 & Very Much Like Me \\
\hline You prefer to study or work alone. & 1.41 & Somewhat Like Me \\
\hline You spend time alone to reflect and think about your life. & 1.48 & Somewhat Like Me \\
\hline You keep a journal or personal diary to record your thoughts. & 0.77 & Nothing Like Me \\
\hline $\begin{array}{c}\text { You would prefer to holiday on a deserted island rather than a resort or cruise ship with } \\
\text { many other people around. }\end{array}$ & 0.45 & Nothing Like Me \\
\hline $\begin{array}{r}\text { You read self-help books, you've been to self-help workshops or you've done similar } \\
\text { work to learn more about yourself. }\end{array}$ & 0.93 & Nothing Like Me \\
\hline You prefer to study alone. & 1.35 & Somewhat Like Me \\
\hline $\begin{array}{r}\text { You think independently. You know how you think and you make up your own mind. } \\
\text { You understand your own strengths and weaknesses. }\end{array}$ & 1.67 & Very Much Like \\
\hline TOTAL & 1.22 & Memewhat Like Me \\
\hline
\end{tabular}


Table 8 below showed the solitary learning style of teacher education students. The item "You are goal oriented and know where you want to go in life, study or work" got the highest mean of 1.90 which means "very much like me" followed by the item "You think independently. You know how you think and you make up your own mind. You understand your own strengths and weaknesses" got a mean of 1.67 which also means "very much like me" and "You have a personal or private interest or hobby that you like to do alone" got a mean of 1.58 which means "very much like me". The succeeding items are interpreted as "somewhat like me": "You spend time alone to reflect and think about your life" got a mean of 1.48; and "You prefer to study or work alone" got a mean of 1.41; "You prefer to study alone" got a mean of 1.35. The items "You read self-help books, you've been to self-help workshops or you've done similar work to learn more about yourself" got a mean of 0.93 which means "nothing like me", "You keep a journal or personal diary to record your thoughts" got a mean of 0.77 which means "nothing like me", "You are happy on your own. You like to do some activities alone and away from others" got a mean of 0.74 which means "nothing like me", and "You would prefer to holiday on a deserted island rather than a resort or cruise ship with many other people around" got a mean of 0.45 which means "nothing like me". The overall mean of the respondents' solitary learning style is 1.22 interpreted as "somewhat like me". As reflected in Table 9 on the academic performance of teacher education students, it shows that of the 31 respondents, 16 or 51.61 percent had the rating from 1.6-2.0 which means "very good", 13 or 41.94 percent had the rating from 2.1-2.5 which means "good", and 2 or 6.45 percent had the rating from 1.1-1.5 which means 'excellent". Results showed that majority of the first year teacher education students had a "very good" performance.

Table 9: Academic Performance of Teacher Education Students.

\begin{tabular}{|c|c|c|c|}
\hline General Average & Frequency & Percent & Interpretation \\
\hline 1.00 & 0 & 0 & Outstanding \\
\hline $1.1-1.5$ & 2 & 6.45 & Excellent \\
\hline $1.6-2.0$ & 16 & 51.61 & Good Good \\
\hline $2.1-2.5$ & 13 & 41.94 & Fair \\
\hline $2.6-3.0$ & 0 & 0 & \\
\hline TOTAL & 31 & 100.00 & \\
\hline
\end{tabular}

Table 10: Learning Style and Students' Academic Performance.

\begin{tabular}{|c|c|l|}
\hline Learning Styles & p & Interpretation \\
\hline Visual & .482 & Not Significant \\
\hline Verbal & .500 & Not Significant \\
\hline Aural & .677 & Not Significant \\
\hline Physical & .700 & Not Significant \\
\hline Logical & .394 & Not Significant \\
\hline Social & .717 & Not Significant \\
\hline Solitary & .365 & Not Significant \\
\hline Total $\alpha=0.05$ & & \\
\hline
\end{tabular}

Table 10 showed the correlation analysis of learning styles using the Pearson's Product Moment Correlation of Coefficient result to a p-value which is greater than the level of significance (0.05) for all learning styles. The visual learning style obtained a p-value of .482 which means "not significant', verbal learning style got a p-value of .500 which means "not significant, aural learning style obtained a p-value of .677 which means "not significant", physical learning style got a UniversePG I www.universepg.com p-value of .700 which means "not significant", logical learning style obtained a p-value of .394 which means "not significant", social learning style got a p-value of .717 which means "not significant" and solitary learning style got a p-value of .365 which means "not significant". The overall result revealed that there is no significant relationship between the preferred learning styles of students and their academic performance; hence, the null hypothesis was accepted. 


\section{CONCLUSION:}

The study's findings and conclusions suggest that: (1) first-year teacher education students have a variety of learning styles, with social learning being the most prevalent. This indicates that first-year teacher education students like to learn in groups or with other people; (2) The first-year teacher education students' ratings vary from 1.6 to 2.0 , indicating that they prefer to learn in groups or with other people which is equivalent to "very good" in the adjectival rating based on the grading system of the university; and (3) The correlation analysis using the Pearson's Product Moment Correlation of Coefficient result to a p-value which is greater than the level of significance (0.05) for all learning styles. Hence, there is no significant relationship between the preferred learning styles of students and their academic performance. Moreover, the teachers of the first year teacher education students should prepare and provide group dynamics or collaborative learning activities being the dominant learning style of the respondents. And for teacher education students to maintain and enhance a "very good" academic performance, the teachers should be flexible in selecting strategies that would cater to the learning styles of students, since learning styles have no significant relationship on the academic performance of the first year teacher education students. The teachers should conduct an inventory of students' learning styles to match the teaching approaches, methods, strategies and techniques to be provided to students. Another study could be tried out using a bigger number of respondents employing triangulation app-roach through interview and classroom observation to assess learning styles. Teachers should undertake an assessment of their students' learning styles in order to fit educational approaches, methods, tactics, and procedures to the students' learning styles. Another study with a larger sample size and a triangulation technique to measure learning styles could be performed.

\section{ACKNOWLEDGEMENT:}

The author wishes to thank the first year teacher education students and the university registrar for their cooperation and help during the data collection process.

\section{CONFLICTS OF INTEREST:}

The author declares there is no conflict of interest to publish it.

UniversePG I www.universepg.com

\section{REFERRENCES:}

1) Abidin, et al. (2011). Learning Styles and Overall Academic Achievement in a Specific Educational. International Journal of Humanities and Social Science, 1(10); 143-152.

http://ijhssnet.com/journals/Vol_1_No_10_August 2011/19.pdf

2) Avellana, Cecilia R. (2006). Learning Styles, Learning Strategies, Teaching Styles and English Achievement: Basis for the Production of Teaching Guides for Basic Freshmen English. LNU, Tacloban City: Unpublished Doctoral Dissertation.

3) De la Cruz, Nimfa C. (2006). Language Learning Strategies, Learning Styles and English Language Performance of First Year College Students. Leyte Normal University, Tacloban City: Unpublished Doctoral Dissertation.

4) Dunn, R., J. Beaudry, and A. Klavas. (1989). Survey of research on learning styles. Educational Leadership March, 50-58.

https://www.ccsenet.org/10.4236/ojpsych.2017.720 $\underline{09}$

5) Fairhurst, A. M. \& Fairhurst, L. L. (1995). Effective teaching, effective learning. California: Davies-Black Publishing. https://www.biblio.com/book/effective-teaching-ef fective-learning-making-personality/d/1185181825

6) Gappi, L. L. (2013). Relationships between Learning Style Preference and Academic Performance of Students. International J. of Educational Research and Technology, 4(2), 70-76. http://www.soeagra.com/ijert/ijertjune2013/11.pdf

7) Husen James and D. H. Postlethwaite. (1994). "Self-Regulated Learning and Academic Achievement". Dissertation Abstract International, UMI, U.S.A.: Bell and Howell Co., 55(12).

8) Jilardi Damavandi, A., Mahyuddin, R., Elias, H., Daud, S. M., \& Shabani, J. (2011). Academic Achievement of Students with Different Learning Styles. International J. of Psychological Studies, 3(2), 186-193.

https://www.ccsenet.org/journal/index.php/ijps/arti cle/view/13343

9) Kolb, D. A. (1984). Experiential learning: experience as the source of learning and development. Englewood Cliffs: Prentice-Hall. 
10) Kolb, D. A. (2005). LSI Technical Manual. Boston: Hay Group.

11) Memletics Learning Styles, (2017). Retrieved April 15, from http://www.crs.sk/storage/memletics-learningstyles-inventory.pdf

12) Oxford, Rebecca, (2001). Language Learning Strategies: An Update. U.S.A.: University of Alabama. Retrieved from:

http://www.cal-org/resources/digital/oxford,01.html

13) Revathy P., and Peruvalluthi V. (2020). Quest and assessment for self-identity in the select
Novel of Arun Joshi, Br. J. Arts Humanit. 2(4), 82-86. https://doi.org/10.34104/bjah.020082086

14) Valle, Jesusa S. (1999). Learning Style Preferences, Academic Achievement of Academic Majors in College. LSC, Tacloban City: Unpublished Doctoral Dissertation. http://www.cal-org/10.28933/ajerr-2020-112307

15) Weerakoon T. (2020). Factors affecting diffusion of entitlement in consumption of scarce commodities: a psychological approach, Br. J. Arts Humanit., 2(6), 113-128.

https://doi.org/10.34104/bjah.02001130128

Citation: Cada BA. (2021). Learning styles and academic performance of teacher education students, Br. J. Arts Humanit., 3(4), 86-96. https://doi.org/10.34104/bjah.021086096 @ () 